\title{
Assessment of Heavy Metals Level in Soil and Vegetables Grown in Peri-Urban Farms around Osun State and the Associated Human Health Risk
}

\author{
Akande, F. O.; Ajayi, S. A. \\ Institute of Ecology and Environmental Studies, Department of Crop Production and Protection, Obafemi Awolowo \\ University, Ile-Ife, Osun State, Nigeria
}

\begin{abstract}
Farming around urban centres (peri-urban farming) is a major source of fresh crop produce, notably vegetables. However, the limitation of land resources and the associated high level of soil contamination from domestic and industrial pollutants are major concerns for the safety of food materials from peri-urban farms. Thus, this study investigated heavy metals ( $\mathrm{As}, \mathrm{Cd}, \mathrm{Cu}, \mathrm{Pb}$ and $\mathrm{Zn})$ concentration in soil and vegetable samples (Amaranthus hybridus and Corchorus olitorius) collected from selected peri-urban farms with a view to providing information on the human health risks associated with consumption of peri-urban vegetables.This study showed that the concentration of investigated heavy metals in the soils of peri-urban farms were within the background range for farming set by $F A O / W H O ~(2002)$ and $E U$ (2006) while appreciable level of these metals were observed in vegetable samples. Arsenic concentration was below detection limit in all samples. Amaranthus showed higher retention capacity for the assayed heavy metals except $\mathrm{Cu}$. Transfer Factor values showed metal uptake by vegetables in the order $\mathrm{Cd}>\mathrm{Zn}>\mathrm{Pb}>\mathrm{Cu}$. The estimated daily intake showed that the highest consumption of $\mathrm{Cd}, \mathrm{Cu}, \mathrm{Pb}$ and $\mathrm{Zn}$ were from Amaranthus. The Health risk index showed high values for $\mathrm{Cd}$ and $\mathrm{Pb}$ but low values for $\mathrm{Cu}$ and $\mathrm{Zn}$ for both Amaranthus and Corchorus. The results obtained in this study regarding the hazard index indicate that vegetables grown in selected peri-urban farms are not safe for consumption.
\end{abstract}

Keywords - Estimated daily intake, Heavy metals, Health risk index, Hazard index, Peri-urban farming, Transfer factor

\section{INTRODUCTION}

Peri-urban farming exists largely within and around boundary zones of cities all over the world (Mohammed and Folorunso, 2015). These periphery zones are characterized by off season vegetable production systems which are affected by or effecting environmental hazard (Ritcher, et al., 1995). The volume and diversity of demand for food stimulated the need for increasing agricultural production around vicinities of cities. Consequently, vegetable production has become intensive in peri-urban areas where there is high population and increasing demand for food (Jansen, 1992).

Irrigation is an essential component of peri-urban agriculture due to competing uses of water in urban areas (de Pascale et al., 2011). The burgeoning demand of water for irrigation has resulted in an increase in the reuse of waste water for agriculture. The use of waste water in peri-urban agriculture is prevalent in several localities around the world (Blumenthal et al., 2000; Ensink et al., 2002; Sharma et al., 2007).

The risks from peri-urban agricultural production may result from excessive agricultural inputs such as inorganic fertilizers, pesticides, sewage sludge and raw organic matter which may contain unwanted residues. Another key concern is the risk of pathogens and heavy metals contamination to consumers due to over dependence of production systems on organic waste and waste water which are readily available (Khai et al., 2007).

Heavy metals exposure is becoming a critical issue especially in developing regions of the world (Adriano, 2001; Jarup, 2003). Heavy metals accumulation in agricultural soil may not only result in contamination of soil but also in increased uptake by food crops which may affect its quality and safety (Muchuweti et al., 2006). Contamination of vegetables by heavy metals has recently received notable research attention because vegetables are consumed relatively in large amount and have the capacity to bioaccumulate heavy metals (Oluwatosin et al., 2010) consequently posing risk to human health.

Quite a number of researches have been carried out on contamination of soil and vegetables by heavy metals (Liu et al., 2005; Mapanda et al., 2005; Rattan et al., 2005). However, empirical data regarding heavy metals 
accumulation in soil and the resultant uptake by food crops through peri-urban farming activities are still needed. Therefore, this study was conducted to investigate heavy metals level in soil and vegetable samples collected from selected peri-urban farms, assess uptake of selected heavy metals by vegetables and to also assess the human health risk associated with consumption of peri-urban vegetables.

\section{MATERIALS AND METHODS}

\section{Study Area/Sampling}

The study areas are geographically located in Osun State, Southwestern part of Nigeria. The State is situated in the tropical rain forest zone. The area is characterized by rainy and dry seasons. The rainy season lasts from middle of March to late October and with peak periods in July and September. The dry season lasts from November to March. Sampling was carried out in seven cities namely; Ede, Ilesa, Ile-Ife, Ila-Orangun, Ikirun, Iwo and Osogbo. These locations were chosen because they represent the typical peri-urban off season vegetable production system in Osun State. Fifteen peri-urban farms were sampled in all from January to April (a period when irrigation was at its peak). Soil and edible vegetable samples from selected peri-urban farms were collected twice, during the first and second planting cycles. Cognizance of farming and production practises peculiar to each peri-urban farm was also taken.
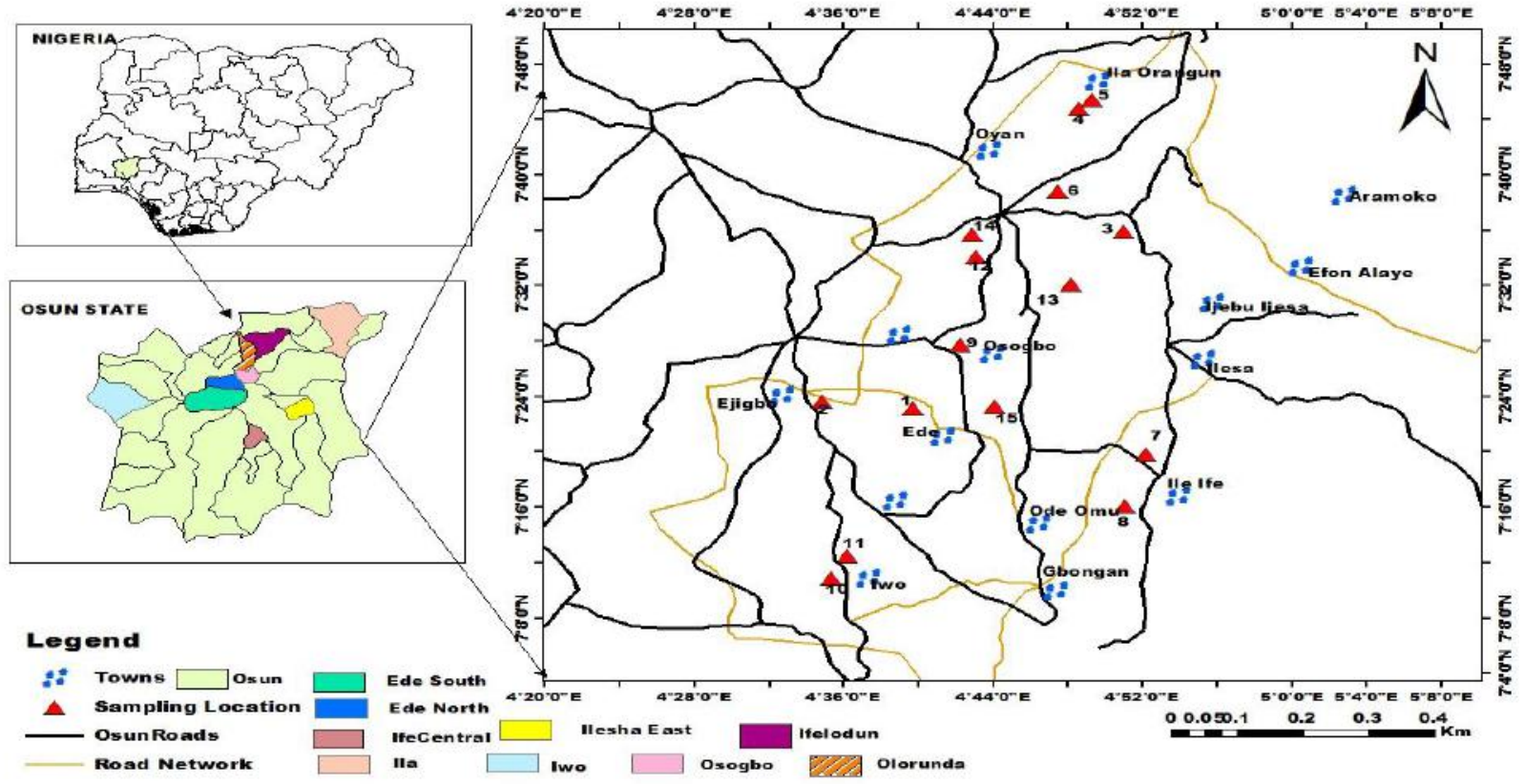

Fig.1: Map of Osun State Showing the Sampling Locations

\section{Soil Sampling, Collection and Characterization}

At each farm, soil samples were randomly collected from the upper horizon $(0-10 \mathrm{~cm})$ using a soil auger and bulked together to form a composite sample. Each soil sample was placed in a labelled black polythene bag, sealed and taken to the laboratory. In the laboratory, soils were air-dried, crushed and sieved through a $<2 \mathrm{~mm}$ mesh, and then firmly sealed in paper envelopes until analysis. Sub-samples were used to determine the desired chemical properties. The soil $\mathrm{pH}$ was determined by the method of Blakemore et al. (1987). Organic carbon was also determined using the chromic acid determination method (Walkley and Black, 1934). Organic matter content of the soil was calculated from Organic carbon.

\section{Plant Sampling, Collection and Preparation}

Whole plant samples were collected by uprooting them from the same site where soils were collected. Two vegetable species Amaranthus hybridus (Amaranth) and Corchorus olitorious (Jute mallow) were selected for health risk assessment because they are the most widely cultivated and consumed leafy vegetables in Southwestern part of Nigeria. Vegetables sampled were between 2-3 months at harvest. After harvesting, plant samples were separated into shoot and root. The shoots were packed into brown envelope and labelled accordingly for laboratory preparation while the roots were discarded. In the laboratory, vegetable shoots were properly washed with distilled water to remove soil debris, weighed and then oven dried at $80^{\circ} \mathrm{C}$ to constant weight. The oven dried samples were pulverized into fine powder using a stainless steel blender and passed through a $2 \mathrm{~mm}$ sieve. The resulting fine powder was stored appropriately, kept at room temperature before analysis and later digested and analyzed for $\mathrm{As}, \mathrm{Cd}, \mathrm{Cu}, \mathrm{Pb}$ and Zn concentrations. 


\section{Control}

An experimental plot in Training and Research Farm of Obafemi Awolowo University, Ile-Ife served as the control site. Vegetable seeds were sown in soil irrigated with unpolluted water and without the application of fertilizers, manures and agrochemicals. Collection of soil and vegetable samples were made twice from January to April at about the same time sampling was being carried out in peri-urban farms.

\section{Digestion of Samples}

One gramme of both soil and vegetable samples were placed into $100 \mathrm{ml}$ beaker separately to which $15 \mathrm{ml}$ of trio-acid mixture $\left(70 \% \quad \mathrm{HNO}_{3}, 65 \% \quad \mathrm{HClO}_{4}\right.$ and $70 \%$ $\mathrm{H}_{2} \mathrm{SO}_{4}$ ) was added in ratio 5:1:1. The mixture was digested at $80^{\circ} \mathrm{C}$ until the solution became clear indicating complete digestion. The resulting solution was then filtered and diluted to $50 \mathrm{ml}$ and later analysed for metals concentration (Ogunfowokan et al., 2013).

\section{Heavy Metals Analysis}

The digested soil and vegetable samples were analysed for their heavy metals ( $\mathrm{As}, \mathrm{Cd}, \mathrm{Cu}, \mathrm{Pb}$ and $\mathrm{Zn}$ ) content using Atomic Absorption Spectrophotometer PG 990 model available at the Central Science Laboratory, O.A.U., Ile-Ife. All concentrations were reported in $\mathrm{mg} / \mathrm{kg}$.

\section{Quality Control}

Measures were taken to check for background contamination and to ensure reliability of data. Blank samples were analyzed after seven samples. All analyses were replicated three times. Precision and accuracy of analysed metals were checked against standard reference material for every heavy metal.

\section{Health Risk Assessments of Metals \\ Transfer Factor (TF)}

Transfer factor was calculated as a ratio of heavy metals concentration in the extracts of soils and vegetables.

$$
\mathrm{PCF}=\frac{\mathrm{C}_{\text {plant }}}{\mathrm{C}_{\text {soil }}}
$$

Where $\mathrm{C}_{\text {plant }}$ and $\mathrm{C}_{\text {soil }}$ represent heavy metal concentration in extracts of vegetables and soils on dry weight basis, respectively.

\section{Daily Intake of Metals (DIM)}

The daily intake (DIM) of heavy metals (As, $\mathrm{Cd}, \mathrm{Cu}, \mathrm{Pb}$, $\mathrm{Zn)}$ was calculated as a product of heavy metals concentration in vegetables and the amount of the respective vegetable consumed. The DIM of metals was determined by the following equation.
Daily intake of metals $(\mathrm{DIM})=\mathrm{DVC} \times \mathrm{VMC}$

DVC = Daily vegetable consumption; $\mathrm{VMC}=$ Mean vegetable metal concentration $(\mathrm{mg} / \mathrm{kg})$

Where daily vegetable consumption was considered to be $98 \mathrm{~g}$ of vegetables per person per day for an average adult of $60 \mathrm{~kg}$ body weight (FAO/WHO, 1999).

\section{Health Risk Index (HRI)}

The health risk index (HRI) for the consumption of contaminated vegetables was estimated as the ratio of the daily intake of metals to the reference oral dose (RfD) for each metal. The HRI $<1$ means the exposed population is safe.

$$
\mathrm{HRI}=\frac{\mathrm{DIM}}{\mathrm{RfD}}
$$

Reference oral dose are 0.003, 0.001, 0.04, 0.004 and 0.3 $\mathrm{mg} / \mathrm{kg} /$ day for $\mathrm{As}, \mathrm{Cd}, \mathrm{Cu}, \mathrm{Pb}$ and $\mathrm{Zn}$ respectively (FAO/WHO, 2013).

\section{Hazard Index (HI)}

The hazard index (HI) as developed by USEPA (2002) was calculated as the summation of the potential health risk index (HRI) arising from all the metals examined.

$\mathrm{HI}=\sum \mathrm{HRI}_{\mathrm{Cd}}+\mathrm{HRI}_{\mathrm{Cu}}+\mathrm{HRI}_{\mathrm{Pb}}+\mathrm{HRI}_{\mathrm{Zn}}$

The value of the hazard index is proportional to the magnitude of the toxicity of the vegetables consumed.

\section{Data Analysis}

Descriptive statistics such as mean and range were used to summarize data collected from sampling sites. Statistical analysis for the cross sectional survey was carried out using Predictive Analytical software for Windows (SAS version 9.2). Analysis of variance $(\mathrm{p}<0.05)$ and Pearson correlation coefficient were used to test for association between the different variables.

\section{RESULTS AND DISCUSSION}

Location of Peri-urban farms, Farming and Production Practices Peculiar to Each Peri-urban Farm

Table 1 shows the specific location of each peri-urban farm, farming and production practices peculiar to each farm. Sixty seven percent of the farmers irrigated their farms with nearby stream while $7 \%$ used shallow well and $13 \%$ each with river tributaries and waste water. About $93 \%$ of the farmers carried out weeding by hand pulling while $7 \%$ applied herbicide. Sixty percent of the farmers enhanced soil fertility by applying inorganic fertilizer, $13 \%$ applied both poultry manure and inorganic fertilizers while the remaining $27 \%$ depended on natural fertility. 


\begin{tabular}{|c|c|c|c|c|}
\hline Farms & Location & Water Source & Soil Fertility Management & $\begin{array}{l}\text { Agrochemical } \\
\text { Input }\end{array}$ \\
\hline 1 & Owode-Ede, by the roadside & Shallow well & $\begin{array}{l}\text { Addition of inorganic } \\
\text { fertilizer }\end{array}$ & - \\
\hline 2 & Outskirt of Ede & Osun river tributaries & $\begin{array}{l}\text { Addition of inorganic } \\
\text { fertilizer and poultry manure }\end{array}$ & - \\
\hline 3 & Ilo-Ajegunle & Nearby stream & $\begin{array}{l}\text { Addition of inorganic } \\
\text { fertilizer and poultry manure }\end{array}$ & - \\
\hline 4 & $\begin{array}{l}\text { Ila-Orangun, near an abandoned } \\
\text { waste depot }\end{array}$ & $\begin{array}{l}\text { Nearby stream } \\
\text { channelled into the } \\
\text { farm }\end{array}$ & $\begin{array}{l}\text { Addition of inorganic } \\
\text { fertilizer }\end{array}$ & - \\
\hline 5 & Ila-Orangun & Nearby stream & $\begin{array}{l}\text { Addition of inorganic } \\
\text { fertilizer }\end{array}$ & - \\
\hline 6 & Ido-Ijesa, near fish ponds & $\begin{array}{l}\text { Stream chanelled into } \\
\text { the farm }\end{array}$ & $\begin{array}{l}\text { Addition of inorganic } \\
\text { fertilizer }\end{array}$ & - \\
\hline 7 & Outskirt of Ile-Ife & $\begin{array}{l}\text { Stream chanelled in to } \\
\text { the farm }\end{array}$ & $\begin{array}{l}\text { By depending on nature } \\
\text { fertility }\end{array}$ & - \\
\hline 8 & $\begin{array}{l}\text { By the road side, along Ede road, } \\
\text { Ile-Ife }\end{array}$ & $\begin{array}{l}\text { Waste water from } \\
\text { O.A.U bioremediation } \\
\text { pond }\end{array}$ & $\begin{array}{l}\text { By depending on nature } \\
\text { fertility }\end{array}$ & - \\
\hline 9 & along Osogbo/Ilie road & Osun river tributaries & $\begin{array}{l}\text { Addition of inorganic } \\
\text { fertilizer }\end{array}$ & - \\
\hline 10 & $\begin{array}{l}\text { Outskirt of Iwo town, near a } \\
\text { waste depot }\end{array}$ & $\begin{array}{l}\text { Stream channeled into } \\
\text { the farm }\end{array}$ & $\begin{array}{l}\text { By depending on nature } \\
\text { fertility }\end{array}$ & - \\
\hline 11 & Between Telemu and Iwo & $\begin{array}{l}\text { Waste water from a } \\
\text { drainage basin }\end{array}$ & $\begin{array}{l}\text { Addition of Inorganic } \\
\text { fertilizer }\end{array}$ & - \\
\hline 12 & Along Osogbo/Ikirun road & Nearby stream & $\begin{array}{l}\text { By depending on nature } \\
\text { fertility }\end{array}$ & - \\
\hline 13 & Outskirt of Osogbo town & Nearby stream & $\begin{array}{l}\text { Addition of inorganic } \\
\text { fertilizer }\end{array}$ & Herbicide \\
\hline 14 & Along Ikirun/Inisha road & Nearby stream & $\begin{array}{l}\text { Addition of inorganic } \\
\text { fertilizer }\end{array}$ & - \\
\hline 15 & Outskirt of Osogbo town & Nearby stream & $\begin{array}{l}\text { Addition of inorganic } \\
\text { fertilizer }\end{array}$ & - \\
\hline
\end{tabular}

\section{Heavy Metals Concentration in Peri-urban Farm Soils} In this study, soil $\mathrm{pH}$ ranged from 5.24 -7.87 indicating a moderately acidic to slightly alkaline $\mathrm{pH}$. It was observed that where soil $\mathrm{pH}$ was recorded near neutral, low concentration of heavy metals was recorded in vegetables than in soil except for $\mathrm{Cd}$. Total organic carbon in the peri-urban farm soils investigated ranged from 0.68$6.32 \%$, suggesting a possibility of metals retention within the soil. Organic matter in soil samples ranged from low to high with values which varied between $1.18-10.87 \%$. Soils of peri-urban farms hold within high amount of organic matter which could be as a result of agricultural applications. Ayolagba and Onmigbuta (2001) clearly showed that high organic matter $(>2.0 \%)$ in soil is favourable for chelation of heavy metals.

The distribution of heavy metals in the soil of peri-urban farms studied was mostly influenced by location of the peri-urban farm, prevailing farming practices and source of water for irrigation. Peri-urban farms located by the roadside, near waste depots and irrigated with waste water showed the highest level of contamination.

Accumulation of $\mathrm{Cd}$ in agricultural soils over time is induced by human activities (Taylor, 1997). Such activities include, excessive application of phosphate fertilizers, domestic and industrial effluents, waste water and pesticides (Kara et al., 2004), from traffic emission and tear and wear of alloyed parts of vehicles. Concentration of $\mathrm{Cd}$ in the soils of various peri-urban farms studied ranged from $0.18-0.63 \mathrm{mg} / \mathrm{kg}$. These values were lower than the natural limit of $3.0-5.0 \mathrm{mg} / \mathrm{kg}$ in soil as given by FAO/WHO (2002) and EU (2006). High Cd concentration in the soil of farm 10 may be due to metals mobility from a nearby waste depot while high level of $\mathrm{Cd}$ in the soils of farms 11 and 13 might come from 
agricultural applications (irrigation water source or the use of inorganic fertilizer as soil amender). The values obtained are similar to those observed by Asawalam and Eke (2006), Njoku and Ayoka (2007) and Oluyemi et al. (2008) who investigated heavy metal concentration and heavy metal pollutants from dump site and agricultural soils in Owerri, Ile-Ife and Osogbo, Nigeria.

The application of manure to agricultural soil increases soil $\mathrm{Cu}$ concentration (Mullins et al., 1982). Elevated levels of $\mathrm{Cu}$ may become harmful to plants, can affect organisms that feed on these plants adversely, and may enter water bodies through run- offs and leaching (Gupta and Charles, 1999). Copper binds strongly to organic matter and minerals in soils and so does not travel far after release (Alloway, 1990; Lentech, 2009). As a result of this, applied $\mathrm{Cu}$ has the tendency to accumulate in soil (Slooff et al., 1989). In this study, concentration of $\mathrm{Cu}$ in the investigated soil samples varied between 2.40-56.17 $\mathrm{mg} / \mathrm{kg}$ which were below the permissible limit set by FAO/WHO (2002) and EU (2006). Soil samples collected from farm 6 and 10 had the highest concentration. Elevated levels of copper in Farm 6 could be traced to the use of $\mathrm{Cu}$ as additive in fish pellet (Bolan et al., 2004) which might have leached into the farm while the elevated level of $\mathrm{Cu}$ observed in farm 10 could be traced to leaching from a nearby waste depot. The concentrations of $\mathrm{Cu}$ in this study were below those reported in soil samples of Torino $(171.00 \mu \mathrm{g} / \mathrm{g})$ by Biasioli et al. (2007) and Guang-dong $(576.50 \mu \mathrm{g} / \mathrm{g})$ by Zhou et al. (2007).

Lead is ranked as one of the most toxic heavy metals affecting man, animal and plant (Zude, 2000), which has been used by mankind for several years because of its wide variety of applications. Lead is found in large amount in many electronic devices, lead acid battery extensively used in car batteries which can end up in soil through corrosion. The concentration of lead in the investigated soil samples ranged from $0.70-36.75 \mathrm{mg} / \mathrm{kg}$. In this study, soil samples from farms 1, 10 and 11 had the highest $\mathrm{Pb}$ concentration. High $\mathrm{Pb}$ concentration observed in farm 1 might be due to past atmospheric deposition derived from combustion of gasoline as a result of the farm's proximity to a highway. High concentration of $\mathrm{Pb}$ observed in Farm 10 and 11 could be from irrigation water source or as a result of metals mobility from a nearby waste depot to the farm through leaching and run -off. Lead levels obtained from this study were lower than those detected in British, England and Wales. Alloway (1995) reported that $\mathrm{Pb}$ content of normal British soil varied between 2 to $300 \mu \mathrm{g} / \mathrm{g}$. Total $\mathrm{Pb}$ content in soils of peri-urban farms studied were below the critical concentration of $300 \mathrm{mg} / \mathrm{kg}$ (FAO/WHO, 2002) and $400 \mathrm{mg} / \mathrm{kg}$ (ICRCL, 1987).
Zinc is used in break lining because of its ability to conduct heat and is released during mechanical abrasion of vehicles, combustion of engine oil and wear and tear of tyres which are emitted into the environment as particles during deposition. In this study, $\mathrm{Zn}$ concentration ranged between 30 to $300 \mathrm{mg} / \mathrm{kg}$ with farms 10 and 13 having the highest concentrations. High concentration of $\mathrm{Zn}$ observed in farm 10 might be due to proximity of the farm to a waste depot from which zinc might have leached into the farm or could also come from irrigation water source. High concentration of $\mathrm{Zn}$ observed in farm 13 might come from herbicide application or irrigation water source. Normal concentration of $\mathrm{Zn}$ in soil ranges from 1 to $300 \mathrm{mg} / \mathrm{kg}$ (FAO/WHO, 2002). Mcgrath (1986) reported that concentration of $\mathrm{Zn}$ in the soil of England and Wales ranged between 5 to $3,648 \mathrm{mg} / \mathrm{kg}$. In this study, $\mathrm{Zn}$ concentration is lower than this range. Ogundele et al. (2015) reported $\mathrm{Zn}$ concentration of between 30.8 to $219.23 \mathrm{mg} / \mathrm{kg}$ in soils collected along heavy traffic road which is similar to values obtained in this study. In this study, concentration of Arsenic was recorded below detection limit in almost all soil samples investigated.

\section{Heavy Metals Concentration in Vegetables Produced from Peri-urban Farms}

Concentration of heavy metals in vegetables collected from peri-urban farms showed significant variation. The variation in heavy metal concentrations in vegetables collected from the same farm may be ascribed to their morphological and physiological differences in uptake, exclusion, and accumulation of heavy metals (Kumar et al., 2009). Concentration of heavy metals analysed in vegetables also varied from one farm to the other which might be due to differences in farming practices.

The concentration of $\mathrm{Cd}, \mathrm{Cu}, \mathrm{Pb}$ and $\mathrm{Zn}$ ranged between $0.19-0.83,0.85-9.60,0.80-11.55,32.00-158.80$ and $0.10-$ $0.58, \quad 2.18-10.33, \quad 0.87-4.70, \quad 14.12-88.50 \mathrm{mg} / \mathrm{kg}$ for Amaranthus and Corchorus respectively. The values of As were below detection limit in vegetables studied. Cadmium concentration in Amaranthus and Corchorus exceeded the permissible limits prescribed by FAO/WHO and EU (2006) for Cd concentration in leafy vegetables except in Corchorus collected from farms 14 and 15. Cadmium level measured in vegetables of peri-urban farms studied was lower than vegetables (10.37-17.79 $\mathrm{mg} / \mathrm{kg}$ ) from Titagarh West Bengal, India (Gupta et al., 2008), vegetables $(25 \mathrm{mg} / \mathrm{kg}$ ) from Turkey (Turkdogan et al., 2002).

Copper concentrations in Amaranthus and Corchorus collected from studied peri-urban farms were below the permissible limits set by FAO/WHO and EU (2006). The mean concentration of $\mathrm{Cu}$ in vegetables $(4.63 \mathrm{mg} / \mathrm{kg}$ for 
Amaranthus and $7.36 \mathrm{mg} / \mathrm{kg}$ for Corchorus) was lower than $\mathrm{Cu}$ content in vegetables $(61.20 \mathrm{mg} / \mathrm{kg})$ from Zhengzhou city, China (Liu et al., 2005) and also lower than the result $(15.66-34.49 \mathrm{mg} / \mathrm{kg})$ obtained in Titagarh West Bengal, India (Gupta et al., 2008). However, the variation in $\mathrm{Cu}$ concentration in the present study was supported by Arora et al. (2008) who reported $\mathrm{Cu}$ level of $5.21-18.2 \mathrm{mg} / \mathrm{kg}$ in vegetables. Higher $\mathrm{Cu}$ concentration was found in Corchorus.

Lead concentrations in vegetables collected from studied peri-urban farms exceeded the permissible limits set by FAO/WHO and EU (2006). Lead content in vegetables was below values reported in Titagarh, West Bengal, $(21.59-57.63 \mathrm{mg} / \mathrm{kg}$ ) and also lower than the mean concentration of $\mathrm{Pb}(409 \mathrm{mg} / \mathrm{kg})$ reported in vegetables from Turkey by Turkdogan et al. (2002) but comparable with $\mathrm{Pb}$ level reported $(0.18-7.75 \mathrm{mg} / \mathrm{kg}$ ) in China (Liu et al., 2005) and in Varanasi, India (3.09-15.74 mg/kg) by Sharma et al., 2008b).

Vegetables collected from peri-urban farms exceeded the permissible limits set for $\mathrm{Zn}$ by $\mathrm{FAO} / \mathrm{WHO}$ and $\mathrm{EU}$ (2006) except in Amaranthus collected from farms 5 and 15 and Corchorus from farms 4, 5, 8, 14 and 15. Zinc concentration in vegetables from studied peri-urban farms was similar to vegetables (32.01-69.26 mg/kg) from Beijing, China (Liu et al., 2005) and also from Rajasthan, India $(21.1-46.4 \mathrm{mg} / \mathrm{kg})$ as reported by Arora et al. (2008) but significantly lower than $\mathrm{Zn}$ concentration in vegetables $(1,038-1,872 \mathrm{mg} / \mathrm{kg}$ ) from Harare, Zimbabwe (Thandi et al., 2004).

There was difference in heavy metals concentration in control soil and vegetable samples compared to heavy metals concentration in soil and vegetable samples from peri-urban farms with significant values $(\mathrm{p}<0.05)$. Mean heavy metals $(\mathrm{Cd}, \mathrm{Cu}, \mathrm{Pb}$ and $\mathrm{Zn})$ concentration in studied peri-urban farm soils, vegetables and control samples are shown in Fig. 2.

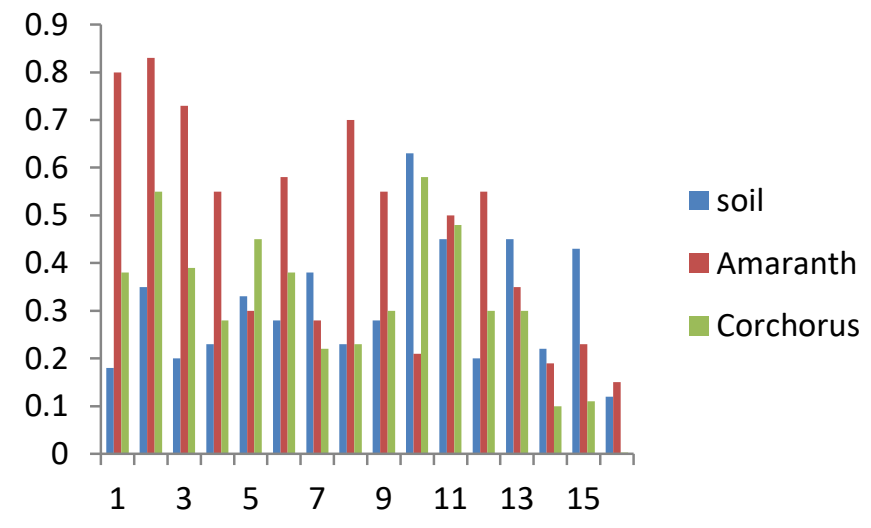

(a)

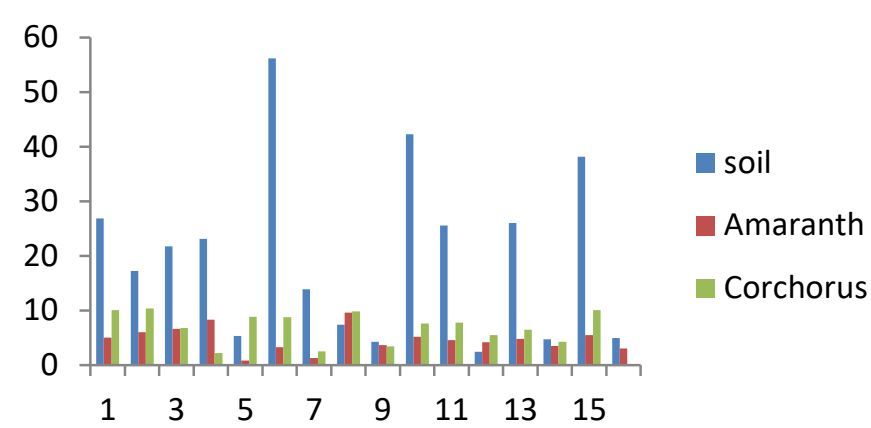

(b)

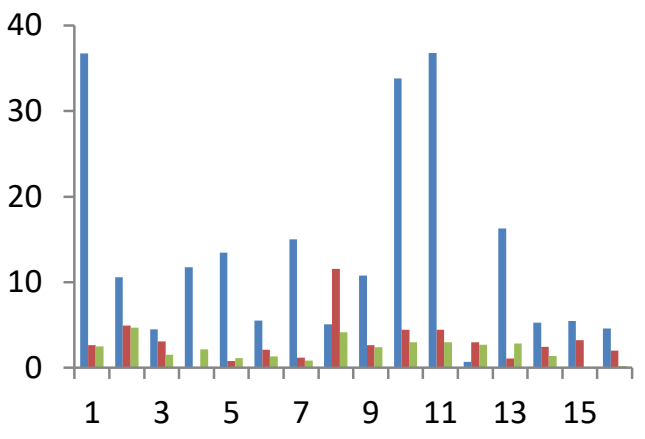

(c)

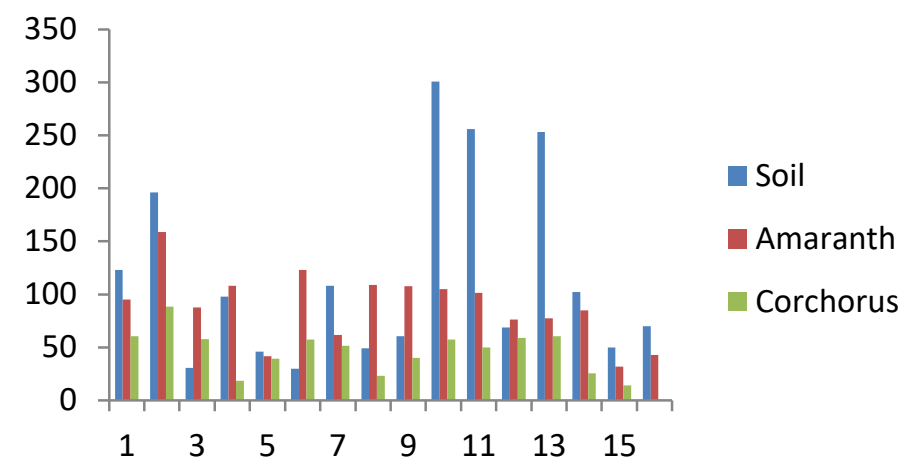

(d)

Fig. 1: Mean heavy metals distribution in peri-urban farm soils, vegetables and control samples: (a) Cd; (b) $\mathrm{Cu}$; (c) $\mathrm{Pb}$; and (e) $\mathrm{Zn}$

\section{Transfer Factor of Individual Metal to Vegetables (TF)}

Transfer factor shows the proportion of heavy metals in the soil taken up by plants (Harrison and Chirgawi, 1989; Smith et al., 1996). The soil-to-plant transfer factor is one of the pathways of human exposure to heavy metals through the food chain. The TF for $\mathrm{Cd}, \mathrm{Cu}, \mathrm{Pb}$ and $\mathrm{Zn}$ ranged from 0.07-4.44, 0.06-0.41, 0.07-4.28, 0.31-4.08 and $0.11-2.11,0.06-2.27,0.06-3.86,0.13-2.63 \mathrm{mg} / \mathrm{kg}$, for Amaranthus and Corchorus respectively. Amaranthus had the highest TF for all metals except $\mathrm{Cu}$. Transfer factor were observed to be higher for $\mathrm{Cd}$ and $\mathrm{Zn}$ whereas lower 
values were found in $\mathrm{Cu}$ and $\mathrm{Pb}$ which varied with sampling site. The high transfer value of $\mathrm{Cd}$ and $\mathrm{Zn}$ indicate strong bioaccumulation of the metals by vegetables. Naser et al. (2011) reported similar result where they observed that $\mathrm{Zn}$ had the highest transfer factor among other metals. There existed strong correlation between $\mathrm{Cd}, \mathrm{Pb}$ and $\mathrm{Zn}$ concentrations in soils and Corchorus collected from peri-urban farms including $\mathrm{Cu}$ and $\mathrm{Zn}$ concentrations in Amaranthus and Corchorus at $(\mathrm{p}<0.05)$ which indicates similar sources of contamination. The general weak correlation between concentration of metals in soils and vegetables which has also been reported (Agbenin et al., 2009) indicates that other sources such as foliar absorption might have contributed to heavy metals load in vegetables. The plant transfer factor is presented in Table 2 .

\begin{tabular}{|c|c|c|c|c|c|}
\hline Farm & TFAs & TFCd & $\mathrm{TFCu}$ & $\mathrm{TFPb}$ & TFZn \\
\hline \multirow[t]{2}{*}{1} & - & $4.44^{\mathrm{a}}$ & $0.19^{\mathrm{a}}$ & $0.07^{\mathrm{a}}$ & $0.77^{\mathrm{a}}$ \\
\hline & - & $2.11^{\mathrm{b}}$ & $0.37^{\mathrm{b}}$ & $0.06^{\mathrm{b}}$ & $2.63^{\mathrm{b}}$ \\
\hline \multirow[t]{2}{*}{2} & - & $2.37^{\mathrm{a}}$ & $0.35^{\mathrm{a}}$ & $0.47^{\mathrm{a}}$ & $0.81^{\mathrm{a}}$ \\
\hline & - & $1.57^{\mathrm{b}}$ & $0.60^{b}$ & $0.44^{\mathrm{b}}$ & $0.45^{b}$ \\
\hline \multirow[t]{2}{*}{3} & - & $3.63^{\mathrm{a}}$ & $0.30^{\mathrm{a}}$ & $0.68^{a}$ & $2.87^{\mathrm{a}}$ \\
\hline & - & $1.96^{\mathrm{b}}$ & $0.31^{\mathrm{b}}$ & $0.34^{\mathrm{b}}$ & $1.88^{\mathrm{b}}$ \\
\hline \multirow[t]{2}{*}{4} & - & $1.96^{\mathrm{a}}$ & $0.41^{\mathrm{a}}$ & $0.87^{\mathrm{a}}$ & $1.10^{\mathrm{a}}$ \\
\hline & - & $1.22^{\mathrm{b}}$ & $0.45^{\mathrm{b}}$ & $0.19^{b}$ & $0.19^{b}$ \\
\hline \multirow[t]{2}{*}{5} & - & $0.92^{\mathrm{a}}$ & $0.15^{\mathrm{a}}$ & $0.06^{\mathrm{a}}$ & $0.91^{\mathrm{a}}$ \\
\hline & - & $1.22^{\mathrm{b}}$ & $1.65^{b}$ & $0.97^{\mathrm{b}}$ & $0.85^{b}$ \\
\hline \multirow[t]{2}{*}{6} & - & $2.09^{a}$ & $0.06^{\mathrm{a}}$ & $0.38^{a}$ & $4.08^{a}$ \\
\hline & - & $1.36^{\mathrm{b}}$ & $0.16^{b}$ & $0.08^{b}$ & $1.92^{\mathrm{b}}$ \\
\hline \multirow[t]{2}{*}{7} & - & $0.73^{\mathrm{a}}$ & $0.09^{\mathrm{a}}$ & $0.08^{a}$ & $0.56^{\mathrm{a}}$ \\
\hline & - & $0.40^{\mathrm{b}}$ & $0.18^{\mathrm{b}}$ & $0.06^{\mathrm{b}}$ & $0.47^{\mathrm{b}}$ \\
\hline \multirow[t]{2}{*}{8} & - & $3.04^{\mathrm{a}}$ & $1.30^{\mathrm{a}}$ & $2.26^{\mathrm{a}}$ & $2.20^{\mathrm{a}}$ \\
\hline & - & $1.00^{\mathrm{b}}$ & $1.33^{\mathrm{b}}$ & $0.81^{\mathrm{b}}$ & $0.47^{\mathrm{b}}$ \\
\hline \multirow[t]{2}{*}{9} & - & $2.00^{\mathrm{a}}$ & $0.85^{\mathrm{a}}$ & $0.24^{\mathrm{a}}$ & $1.78^{\mathrm{a}}$ \\
\hline & - & $0.11^{\mathrm{b}}$ & $0.06^{\mathrm{b}}$ & $0.32^{\mathrm{b}}$ & $0.66^{\mathrm{b}}$ \\
\hline \multirow[t]{2}{*}{10} & - & $0.34^{\mathrm{a}}$ & $0.12^{\mathrm{a}}$ & $0.35^{\mathrm{a}}$ & $0.35^{\mathrm{a}}$ \\
\hline & - & $0.92^{\mathrm{b}}$ & $0.18^{b}$ & $0.15^{\mathrm{b}}$ & $0.19^{b}$ \\
\hline \multirow[t]{2}{*}{11} & - & $1.05^{\mathrm{a}}$ & $0.18^{\mathrm{a}}$ & $0.12^{\mathrm{a}}$ & $0.40^{\mathrm{a}}$ \\
\hline & - & $0.94^{\mathrm{b}}$ & $0.30^{\mathrm{b}}$ & $0.08^{\mathrm{b}}$ & $0.20^{\mathrm{b}}$ \\
\hline \multirow[t]{2}{*}{12} & - & $2.75^{\mathrm{a}}$ & $1.75^{\mathrm{a}}$ & $4.28^{\mathrm{a}}$ & $1.11^{\mathrm{a}}$ \\
\hline & - & $1.50^{\mathrm{b}}$ & $2.27^{\mathrm{b}}$ & $3.86^{\mathrm{b}}$ & $0.85^{\mathrm{b}}$ \\
\hline \multirow[t]{2}{*}{13} & - & $0.78^{a}$ & $0.18^{\mathrm{a}}$ & $0.07^{\mathrm{a}}$ & $0.31^{\mathrm{a}}$ \\
\hline & - & $0.67^{\mathrm{b}}$ & $0.25^{\mathrm{b}}$ & $0.18^{\mathrm{b}}$ & $0.13^{b}$ \\
\hline \multirow[t]{2}{*}{14} & - & $0.56^{\mathrm{a}}$ & $0.75^{\mathrm{a}}$ & $0.26^{\mathrm{a}}$ & $0.83^{\mathrm{a}}$ \\
\hline & - & $0.45^{\mathrm{b}}$ & $0.26^{\mathrm{b}}$ & $0.29^{b}$ & $0.25^{\mathrm{b}}$ \\
\hline \multirow[t]{2}{*}{15} & - & $0.50^{\mathrm{a}}$ & $0.14^{\mathrm{a}}$ & $0.01^{\mathrm{a}}$ & $0.86^{\mathrm{a}}$ \\
\hline & - & $0.25^{\mathrm{b}}$ & $0.26^{b}$ & $0.19^{b}$ & $0.28^{b}$ \\
\hline
\end{tabular}

a - TF of individual metal from soil to Amaranthus hybridus

$\mathrm{b}-\mathrm{TF}$ of individual metal from soil to Corchorus olitorius

\section{Estimated Daily Intake of Metals (DIM)}

The estimated daily intake of metals for adult is given in Table 3. The pathway for $\mathrm{Cd}, \mathrm{Cu}, \mathrm{Pb}$ and $\mathrm{Zn}$ intake was presumed to be vegetable consumption. The DIM of $\mathrm{Cd}$, $\mathrm{Cu}, \mathrm{Pb}$ and $\mathrm{Zn}$ ranged from $0.0003-0.001,0.00021-0.016$, $0.002-0.014,0.053-0.159$ and $0.0002-0.0016,0.004-$ $0.016, \quad 0.0017-0.0076$ and $0.023-0.144 \mathrm{mg} / \mathrm{kg} / \mathrm{day}$, respectively from consumption of Amaranthus and Corchorus respectively. The results for the evaluation of $\mathrm{DIM}$ for $\mathrm{Cd}, \mathrm{Cu}, \mathrm{Pb}$ and $\mathrm{Zn}$ showed that the highest intake of $\mathrm{Cd}, \mathrm{Cu}, \mathrm{Pb}$ and $\mathrm{Zn}$ were from consumption of Amaranthus. The estimated DIM when compared to recommended daily intake/ allowance for heavy metals (USEPA, 2009) was below the recommended daily 
intake/ allowance for metals studied. Zhuang et al. (2009) and Sharma et al. (2010) also reported DIM values lower than the allowable daily intake limits but Sridhara et al.
(2007) recorded DIM values for heavy metals that were lower than tolerable daily intake limits.

Table.3: Daily Metals Intake Estimate $\left(\mathrm{mg}^{-1} \mathrm{~kg}^{-1}\right.$ person $\left.^{-1} \mathrm{~d}^{-1}\right)$ from Consumption of Amaranthus hybridus and Corchorus olitorious in Adult

\begin{tabular}{|c|c|c|c|c|c|}
\hline Farm & As & $\mathrm{Cd}$ & $\mathrm{Cu}$ & $\mathrm{Pb}$ & $\mathrm{Zn}$ \\
\hline \multirow[t]{2}{*}{1} & - & $0.0010^{\mathrm{a}}$ & $0.0080^{\mathrm{a}}$ & $0.0040^{\mathrm{a}}$ & $0.1550^{\mathrm{a}}$ \\
\hline & - & $0.0006^{\mathrm{b}}$ & $0.0160^{\mathrm{b}}$ & $0.0041^{\mathrm{b}}$ & $0.0920^{\mathrm{b}}$ \\
\hline \multirow[t]{2}{*}{2} & - & $0.0010^{\mathrm{a}}$ & $0.0100^{\mathrm{a}}$ & $0.0080^{\mathrm{a}}$ & $0.2590^{\mathrm{a}}$ \\
\hline & - & $0.0008^{b}$ & $0.0168^{b}$ & $0.0076^{\mathrm{b}}$ & $0.1440^{\mathrm{b}}$ \\
\hline \multirow[t]{2}{*}{3} & - & $0.0012^{\mathrm{a}}$ & $0.0110^{\mathrm{a}}$ & $0.0050^{\mathrm{a}}$ & $0.1430^{\mathrm{a}}$ \\
\hline & - & $0.0006^{\mathrm{a}}$ & $0.0110^{\mathrm{a}}$ & $0.0025^{\mathrm{a}}$ & $0.0920^{\mathrm{a}}$ \\
\hline \multirow[t]{2}{*}{4} & - & $0.0009^{\mathrm{b}}$ & $0.0150^{\mathrm{b}}$ & $0.0140^{\mathrm{b}}$ & $0.1760^{\mathrm{b}}$ \\
\hline & - & $0.0004^{\mathrm{a}}$ & $0.0170^{\mathrm{a}}$ & $0.0035^{\mathrm{a}}$ & $0.0290^{\mathrm{a}}$ \\
\hline \multirow[t]{2}{*}{5} & - & $0.0005^{\mathrm{b}}$ & $0.0010^{\mathrm{b}}$ & $0.0013^{b}$ & $0.0680^{\mathrm{b}}$ \\
\hline & - & $0.0007^{\mathrm{a}}$ & $0.0140^{\mathrm{a}}$ & $0.0019^{\mathrm{a}}$ & $0.0640^{\mathrm{a}}$ \\
\hline \multirow[t]{2}{*}{6} & - & $0.0009^{b}$ & $0.0054^{\mathrm{b}}$ & $0.0030^{\mathrm{b}}$ & $0.2010^{\mathrm{b}}$ \\
\hline & - & $0.0006^{\mathrm{s}}$ & $0.0140^{\mathrm{a}}$ & $0.0022^{\mathrm{a}}$ & $0.0940^{\mathrm{a}}$ \\
\hline \multirow[t]{2}{*}{7} & - & $0.0005^{\mathrm{b}}$ & $0.0021^{b}$ & $0.0019^{b}$ & $0.1009^{b}$ \\
\hline & - & $0.0004^{\mathrm{a}}$ & $0.0040^{\mathrm{a}}$ & $0.0014^{\mathrm{a}}$ & $0.0843^{\mathrm{a}}$ \\
\hline \multirow[t]{2}{*}{8} & - & $0.0011^{\mathrm{b}}$ & $0.0160^{\mathrm{b}}$ & $0.0190^{\mathrm{b}}$ & $0.1780^{b}$ \\
\hline & - & $0.0004^{\mathrm{a}}$ & $0.0160^{\mathrm{a}}$ & $0.0067^{a}$ & $0.0380^{\mathrm{a}}$ \\
\hline \multirow[t]{2}{*}{9} & - & $0.0009^{b}$ & $0.0060^{\mathrm{b}}$ & $0.0040^{\mathrm{b}}$ & $0.1760^{\mathrm{b}}$ \\
\hline & - & $0.0004^{\mathrm{a}}$ & $0.0060^{\mathrm{a}}$ & $0.0039^{\mathrm{a}}$ & $0.0660^{\mathrm{a}}$ \\
\hline \multirow[t]{2}{*}{10} & - & $0.0003^{\mathrm{b}}$ & $0.0085^{\mathrm{b}}$ & $0.0079^{\mathrm{b}}$ & $0.1715^{\mathrm{b}}$ \\
\hline & - & $0.0009^{\mathrm{a}}$ & $0.0120^{\mathrm{a}}$ & $0.0057^{a}$ & $1.0939^{\mathrm{a}}$ \\
\hline \multirow[t]{2}{*}{11} & - & $0.0008^{b}$ & $0.0070^{\mathrm{b}}$ & $0.0073^{\mathrm{b}}$ & $0.1657^{b}$ \\
\hline & - & $0.0008^{\mathrm{a}}$ & $0.0127^{\mathrm{a}}$ & $0.0049^{\mathrm{a}}$ & $0.0820^{\mathrm{a}}$ \\
\hline \multirow[t]{2}{*}{12} & - & $0.0009^{b}$ & $0.0069^{b}$ & $0.0050^{\mathrm{b}}$ & $0.1245^{b}$ \\
\hline & - & $0.0005^{\mathrm{a}}$ & $0.0089^{a}$ & $0.0044^{a}$ & $0.0960^{\mathrm{a}}$ \\
\hline \multirow[t]{2}{*}{13} & - & $0.0006^{\mathrm{b}}$ & $0.0078^{\mathrm{b}}$ & $0.0017^{\mathrm{b}}$ & $0.1260^{b}$ \\
\hline & - & $0.0005^{\mathrm{a}}$ & $0.0140^{\mathrm{a}}$ & $0.0045^{\mathrm{a}}$ & $0.0990^{\mathrm{a}}$ \\
\hline \multirow[t]{2}{*}{14} & - & $0.0003^{b}$ & $0.0057^{b}$ & $0.0040^{\mathrm{b}}$ & $0.1388^{b}$ \\
\hline & - & $0.0002^{\mathrm{a}}$ & $0.0068^{\mathrm{a}}$ & $0.0023^{\mathrm{a}}$ & $0.0420^{\mathrm{a}}$ \\
\hline \multirow[t]{2}{*}{15} & - & $0.0004^{\mathrm{b}}$ & $0.0070^{\mathrm{b}}$ & $0.0053^{\mathrm{b}}$ & $0.0900^{\mathrm{b}}$ \\
\hline & - & $0.0002^{\mathrm{a}}$ & $0.0160^{\mathrm{a}}$ & $0.0017^{\mathrm{a}}$ & $0.0230^{\mathrm{a}}$ \\
\hline RDI & - & 0.0640 & 10.000 & 0.2400 & 40.000 \\
\hline
\end{tabular}

a - Daily metal intake estimate from consumption of Amaranthus hybridus b- Daily metal intake estimate from consumption of Corchorus olitorius

\section{Potential Health Risk Index (HRI) and Hazard Index (HI)}

Food chain is one of the most significant routes of human exposure to heavy metals. Consumption of contaminated vegetables has been pinpointed as one of the major pathways of human exposure to toxic heavy metals. The $\mathrm{HRI}$ for $\mathrm{Cd}, \mathrm{Cu}, \mathrm{Pb}$ and $\mathrm{Zn}$ ranged from $0.30-1.20,0.03-$ $0.38,0.10-4.75,0.18-0.86$ and $0.20-0.90,0.10-0.43,0.35$ 1.68 and $0.08-0.48$ for consumption of Amaranthus and Corchorus respectively. The result showed high values for $\mathrm{Cd}$ and $\mathrm{Pb}$ but low values for $\mathrm{Cu}$ and $\mathrm{Zn}$ for both Amaranthus and Corchorus. Ikeda et al. (2000) and
Zhuang et al. (2009) also observed HRI values for $\mathrm{Cd}$ and $\mathrm{Pb}$ which were above permissible limits in vegetables and cereals. Considering individual heavy metal, the health risk index is in the order $\mathrm{Pb}>\mathrm{Cd}>\mathrm{Zn}>\mathrm{Cu}$ but when considering vegetables type, the health risk index was Amaranthus $>$ Corchorus. The calculated HRI for $\mathrm{Cd}$ and $\mathrm{Pb}$ from consumption of Amaranthus was greater than 1 in farms 1, 2, 3, 8 and farms 1, 2, 3, 4, 8, 9, 10, 11, 12, respectively. Health risk index for $\mathrm{Pb}$ from consumption of Corchorus was greater than 1 in farms $1,2,8,10,11$, 12 and 13 which means that inhabitants around farms 1 , 2,3 , and 8 are at significant risk of $\mathrm{Cd}$ toxicity from 
consumption of Amaranthus while inhabitants around farms 1, 2, 3, 4, 8, 9, 10,11, 12, 13 are exposed to risk of $\mathrm{Pb}$ toxicity from consumption of either Amaranthus or Corchorus. The estimated hazard index for all the assayed heavy metals in Amaranthus and Corchorus of all the peri-urban farms studied was greater than 1 . The result of this study regarding the $\mathrm{HI}$ revealed that vegetables grown in selected peri-urban farms are not safe for consumption. The HRI and HI of heavy metals through consumption of vegetables are presented in Table 4.

Table.4: Potential Health Risk and Hazard Index of Heavy Metals through Intake of Amaranthus hybridus and Corchorus olitorius in Adult

\begin{tabular}{|c|c|c|c|c|c|c|}
\hline Farm & As & $\mathrm{Cd}$ & $\mathrm{Cu}$ & $\mathrm{Pb}$ & $\mathrm{Zn}$ & $\mathrm{HI}$ \\
\hline \multirow[t]{2}{*}{1} & - & $1.00^{\mathrm{a}}$ & $0.21^{\mathrm{a}}$ & $1.00^{\mathrm{a}}$ & $0.52^{\mathrm{a}}$ & $2.73^{\mathrm{a}}$ \\
\hline & - & $0.60^{\mathrm{b}}$ & $0.40^{\mathrm{b}}$ & $1.03^{b}$ & $0.31^{\mathrm{b}}$ & $2.30^{\mathrm{b}}$ \\
\hline \multirow[t]{2}{*}{2} & - & $1.00^{\mathrm{a}}$ & $0.24^{\mathrm{a}}$ & $2.03^{\mathrm{a}}$ & $0.86^{\mathrm{a}}$ & $4.13^{\mathrm{a}}$ \\
\hline & - & $0.80^{\mathrm{b}}$ & $0.42^{\mathrm{b}}$ & $1.90^{\mathrm{b}}$ & $0.48^{\mathrm{b}}$ & $3.60^{\mathrm{b}}$ \\
\hline \multirow[t]{2}{*}{3} & - & $1.20^{\mathrm{a}}$ & $0.28^{\mathrm{a}}$ & $1.25^{\mathrm{a}}$ & $0.48^{\mathrm{a}}$ & $3.21^{\mathrm{a}}$ \\
\hline & - & $0.64^{\mathrm{b}}$ & $0.28^{\mathrm{b}}$ & $0.63^{b}$ & $0.31^{\mathrm{b}}$ & $1.86^{\mathrm{b}}$ \\
\hline \multirow[t]{2}{*}{4} & - & $0.90^{\mathrm{a}}$ & $0.38^{\mathrm{a}}$ & $3.50^{\mathrm{a}}$ & $0.59^{\mathrm{a}}$ & $5.37^{\mathrm{a}}$ \\
\hline & - & $0.40^{\mathrm{b}}$ & $0.43^{\mathrm{b}}$ & $0.88^{\mathrm{b}}$ & $0.09^{b}$ & $1.80^{\mathrm{b}}$ \\
\hline \multirow[t]{2}{*}{5} & - & $0.49^{\mathrm{a}}$ & $0.03^{\mathrm{a}}$ & $0.33^{\mathrm{a}}$ & $0.22^{\mathrm{a}}$ & $1.07^{\mathrm{a}}$ \\
\hline & - & $0.70^{\mathrm{b}}$ & $0.35^{\mathrm{b}}$ & $0.48^{b}$ & $0.21^{\mathrm{b}}$ & $1.74^{\mathrm{b}}$ \\
\hline \multirow[t]{2}{*}{6} & - & $0.95^{\mathrm{a}}$ & $0.14^{\mathrm{a}}$ & $0.75^{\mathrm{a}}$ & $0.67^{\mathrm{a}}$ & $2.51^{\mathrm{a}}$ \\
\hline & - & $0.60^{\mathrm{b}}$ & $0.35^{\mathrm{b}}$ & $0.55^{\mathrm{b}}$ & $0.31^{\mathrm{b}}$ & $1.81^{\mathrm{b}}$ \\
\hline \multirow[t]{2}{*}{7} & - & $0.50^{\mathrm{a}}$ & $0.05^{\mathrm{a}}$ & $0.48^{\mathrm{a}}$ & $0.33^{\mathrm{a}}$ & $1.36^{\mathrm{a}}$ \\
\hline & - & $0.40^{\mathrm{b}}$ & $0.10^{\mathrm{b}}$ & $0.35^{\mathrm{b}}$ & $0.30^{\mathrm{b}}$ & $1.15^{\mathrm{b}}$ \\
\hline \multirow[t]{2}{*}{8} & - & $1.10^{\mathrm{a}}$ & $0.40^{\mathrm{a}}$ & $4.75^{\mathrm{a}}$ & $0.59^{\mathrm{a}}$ & $6.84^{\mathrm{a}}$ \\
\hline & - & $0.40^{\mathrm{b}}$ & $0.40^{\mathrm{b}}$ & $1.68^{b}$ & $0.13^{b}$ & $2.61^{b}$ \\
\hline \multirow[t]{2}{*}{9} & - & $0.90^{\mathrm{a}}$ & $0.15^{\mathrm{a}}$ & $1.00^{\mathrm{a}}$ & $0.22^{\mathrm{a}}$ & $2.27^{\mathrm{a}}$ \\
\hline & - & $0.40^{\mathrm{b}}$ & $0.15^{\mathrm{b}}$ & $0.98^{\mathrm{b}}$ & $0.22^{\mathrm{b}}$ & $1.75^{\mathrm{b}}$ \\
\hline \multirow[t]{2}{*}{10} & - & $0.30^{\mathrm{a}}$ & $0.21^{\mathrm{a}}$ & $1.98^{\mathrm{a}}$ & $0.57^{\mathrm{a}}$ & $3.06^{\mathrm{a}}$ \\
\hline & - & $0.90^{\mathrm{b}}$ & $0.30^{\mathrm{b}}$ & $1.43^{b}$ & $0.31^{\mathrm{b}}$ & $2.94^{b}$ \\
\hline \multirow[t]{2}{*}{11} & - & $0.80^{\mathrm{a}}$ & $0.18^{\mathrm{a}}$ & $1.83^{\mathrm{a}}$ & $0.55^{\mathrm{a}}$ & $3.36^{\mathrm{b}}$ \\
\hline & - & $0.80^{\mathrm{b}}$ & $0.32^{\mathrm{b}}$ & $1.23^{\mathrm{b}}$ & $0.27^{b}$ & 2.62 \\
\hline \multirow[t]{2}{*}{12} & - & $0.90^{\mathrm{a}}$ & $0.17^{\mathrm{a}}$ & $1.25^{\mathrm{a}}$ & $0.42^{\mathrm{a}}$ & 2.74 \\
\hline & - & $0.50^{\mathrm{b}}$ & $0.22^{\mathrm{b}}$ & $1.10^{\mathrm{b}}$ & $0.32^{\mathrm{b}}$ & 1.09 \\
\hline \multirow[t]{2}{*}{13} & - & $0.60^{\mathrm{a}}$ & $0.20^{\mathrm{a}}$ & $0.43^{\mathrm{a}}$ & $0.42^{\mathrm{a}}$ & 1.65 \\
\hline & - & $0.50^{\mathrm{b}}$ & $0.28^{\mathrm{b}}$ & $1.13^{\mathrm{b}}$ & $0.27^{b}$ & 2.24 \\
\hline \multirow[t]{2}{*}{14} & - & $0.30^{\mathrm{a}}$ & $0.14^{\mathrm{a}}$ & $0.10^{\mathrm{a}}$ & $0.46^{\mathrm{a}}$ & 1.00 \\
\hline & - & $0.20^{\mathrm{b}}$ & $0.17^{b}$ & $0.58^{\mathrm{b}}$ & $0.32^{\mathrm{b}}$ & 1.09 \\
\hline \multirow[t]{2}{*}{15} & - & $0.40^{\mathrm{a}}$ & $0.18^{\mathrm{a}}$ & $0.13^{\mathrm{a}}$ & $0.30^{\mathrm{a}}$ & 1.01 \\
\hline & - & $0.20^{\mathrm{b}}$ & $0.40^{\mathrm{b}}$ & $0.43^{\mathrm{b}}$ & $0.08^{\mathrm{b}}$ & 1.11 \\
\hline
\end{tabular}

$\mathrm{HI}=$ hazard index

a - HRI of heavy metals from consumption of Amaranthus hybridus

b - HRI of heavy metals from consumption of Corchorus olitorius

\section{CONCLUSION}

In this study, investigated heavy metals concentration in the soils of studied peri-urban farms were within the background range for farming set by FAO/WHO (2002) and EU (2006). The results obtained from vegetables analysis for $\mathrm{Cd}, \mathrm{Cu}, \mathrm{Pb}$ and $\mathrm{Zn}$ indicate appreciable level of these metals in all the samples. Arsenic concentration was below detection limit in soil and vegetable samples collected from peri-urban farms. Average metal concentration in vegetables was higher in Amaranthus compared to Corchorus which suggest that Amaranthus has relatively higher bioaccumulation capacity compared to Corchorus. However, Corchorus showed higher retention capacity for $\mathrm{Cu}$ revealing potential use of Corchorus as a plant for environmental monitoring and soil remediation of $\mathrm{Cu}$. The variability of heavy metals transfer factor was shown to be inherently strong for $\mathrm{Cd}$ and $\mathrm{Zn}$ but mild for $\mathrm{Cu}$ and $\mathrm{Pb}$. This study also revealed that vegetables under study may constitute significant health risk to consumers as they were found to contain higher than allowable level of heavy metals such as $\mathrm{Cd}$ and $\mathrm{Pb}$ which are toxic. Also, the hazard index of heavy 
metals in all the peri-urban farms studied was $>1$ which signifies relative presence of health risks related to ingestion of contaminated vegetables.

\section{REFERENCES}

[1] Adriano, D. C. (2001): Trace elements in terrestrial Environment. Biogeochemistry, Bioavailability and Risk of Metals. Springer Verlag, New York, pp. 353.

[2] Agbenin, J. O., Danko, M. and Welp, G. (2009): Soil and vegetable compositional relationships of eight potentially toxic heavy metals in urban garden fields from northern Nigeria. Journal of Food and Agriculture.189, 49-54.

[3] Alloway, B. J. (1990): Soil Processes and the behavior of metals. In: Alloway, B. J. (ed.). Heavy metals in soil. Blackie and Son Ltd. Glasgow, pp. 100-121.

[4] Alloway, B. J. (1995): The origin of heavy metals in soils. In: Alloway, B. J. (ed.), heavy metals in soils. Blackie Academic and Professional, London, UK. pp.38-57.

[5] Arora, M., Kiran, B., Rain, S., Rani, A., Kaura, B. and Mittal, N. (2008): Heavy metals accumulation in Vegetables irrigated with water from different sources. Food Chemistry. 11, 811-815.

[6] Asawalam, D. O. and Eke, C. I. (2006): Trace metal concentration in soils used for waste disposal around Owerri, Nigeria. In: Proceedings of the $40^{\text {th }}$ Conference of the Agricultural Society of Nigeria, Michael Okpara University of Agriculture, Umudike, Abia State, Nigeria. pp. 427-430.

[7] Ayolagba, G. A. and Onwugbata, G. C. (2001): Suitability comparison of waste disposal site. 27th Proceedings of the Annual Conference of the Soil Science of Nigeria. University of Calabar, Calabar, Nigeria, pp. 23-25.

[8] Biasioli, M., Grcman, H., Kralj, T. Madrid, F., Diaz, B. and Ajmone-Marsan, F. (2007): Potentially Toxic Elements Contamination in Urban soils: A Comparison of Three European Cities. ASA, CSSA and SSSA, Journal of Environmental Quality. 36, 70-79. doi: 10.2134/jeq2006.0254.

[9] Blakemore, L. C., Searle, P. L. and Daly, B. K. (1987): Methods for chemical analysis of soils. New Zealand Soil Bureau Scientific Report, 80: 103 pp.

[10] Blumenthal, U., Peasey, A., Ruiz-Palacios, G., Mara, D. D. (2000): Guidelines for wastewater reuse in agriculture and aquaculture: recommended revisions based on new research evidence. Task No. 68, Part 1. Retrieved from persistent URL http://www.lboro.ac.uk/well/resources/wellstudies/full-reports-pdf on 10th of Jan, 2017.
[11]Bolan, N. S., Surinder, S., Jiafa, L., Rita, B. and Jagrati S. (2004): Gaseous emissions of nitrogen from grazed pastures: Processes, measurement and modeling, environmental implication and mitigation. Advances in Agronomy. 84, 37-120.

[12] De Pascale S., Costa, L. D., Vallone, S., Barbieri, G. and Maggio, A. (2011): Increasing water use efficiency in vegetable crop production: from plant to irrigation systems efficiency. Horticultural Technology. 21(3), 301-308.

[13] Ensink, J. H., van der Hoek, W., Matsuno, Y., Munir, S. and Aslam, M. R. (2002): Use of untreated wastewater in peri urban agriculture in Pakistan: Risks and Opportunities. Res. Rep. 64, Colombo: International Water Management. Institute. (IWMI).

[14] European Union (2006): Heavy metals in wastes, European Commission on Environment (http://ec.europa.eu/environment/waste/studies/pdf/ heavy metals report.pdf)

[15]FAO (1999): Urban and Peri-Urban Agriculture. Report to the FAO Commercial.

[16]FAO/WHO (2002): Codex Alimentarius Commission: Food additives and Contaminants. Joint FAO/WHO food standard programme, ALINORM 01/12A:1-289

[17]FAO/WHO, (2013): Joint FAO/WHO food standard programme codex committee on contaminants in foods, fifth session pp 64-89Agriculture. (Coag) Meeting from Jan. 25-26. FAO, Rome.

[18] Gupta, G. and Charles, S. (1999): Trace elements in soils fertilized with poultry litter. Poultry Science. 78, 1695-1698.

[19] Gupta, N., Khan, D. K. and Santra, S. C. (2008): An assessment of heavy metal contamination in vegetables grown in wastewater-irrigated of Titagarh, West Bengal, India. Bulletin of Environmental Contamination and Toxicology. 80, 115-118.

[20]Harrison, R. M. and Chirgawi, M. B. (1989): The assessment of air, soil as contributors of some trace metals to vegetable plants. Use of a filtered air growth cabinet. Science of the Total Environment. 83(1-2), 13-34.

[21] ICRCL, (1987): Interdepartmental Committee on the redevelopment of contaminated land. Guidance on the assessment and redevelopment of contaminated land. Guidance Note. 59/83. Department of Environment, London, pp. 388-394.

[22] Ikeda, M., Zhang, Z. W., Shimbo, S., Watanabe, T., Nakatsuka, H., Moon, C. S., Matsuda-Inoguchi, N. and Higashikawa, K. (2000): Urban population exposure to lead and cadmium in east and south-east 
Asia. Science of the Total Environment. 249, 373384.

[23] Jansen, H. G. P. (1992): Supply and demand of AVRDC mandate crops in Asia: implications of past trendsfor future developments. AVRDC Working Paper Series no. 4, vol. 84. Asian Vegetable Research and Development Center, Taiwan.

[24] Jarup, L. (2003): Hazards of heavy metal contamination. British Medical Bulletin. 68, 167182.

[25] Kara, E. E., Pirlak, U. and Ozdilek, H. G. (2004): Evaluation of heavy metals $(\mathrm{Cd}, \mathrm{Cu}, \mathrm{Ni}, \mathrm{Pb}$ and $\mathrm{Zn})$ distribution in sowing regions of potato fields in the province of Nigde, Turkey. Water, Air and Soil Pollution. 153, 173-186.

[26] Khai, N. M., Pham Q. H. and Irigrid, O. (2007): Nutrient flow in small scale peri-urban farming system in Southeast Asia- A case study in Hanoi. Agriculture, Ecosystem and Environment. 122, 192202.

[27] Kumar, B. M., Ramachandra, P. K., Vindar, D. N. (2009): Agroforesty as a strategy for carbon sequestration. Journal of Plant Nutrition and Soil Science. 172(1), 10-23.

[28]Lenntech, W. T. (2009): Chemical properties, Health and Environmental Effects of $\mathrm{Cu}$. Lenntech Water Treatment and Purification Holding, B. V., 3 p.

[29]Liu, W. H., Zhao, J. Z., Ouyang, Z. Y., Solderland, L. and Liu, G. H. (2005): Impacts of sewage irrigation on heavy metal distribution and contamination in Beijing, China. Environment International 32: 805-812.

[30] Mapanda, F., Mangwayana, E. N., Nyamangara, J. and Giller, K. E. (2005): The effect of long-term irrigation using wastewater on heavy metal contents of soils under vegetables in Harare, Zimbabwe. Agriculture, Ecosystem and Environment. 107, 151165.

[31] Mcgrath S. P. (1986): The range of metal concentration in top soil of England and Wales in relation to soil protection guidelines. In: Hempill, D. D. (ed.), Trace substances in Environment. University of Missouri, Columbia, 36p.

[32] Mohammed, S. A. and Folorunsho, J. O. (2015): Heavy metals concentration in soil and Amaranthus retroflexus grown on irrigated farmlands in the Makara Area, Kaduna, Nigeria. Journal of Geography and Regional Planning. 8(8), 210-217.

[33] Muchuweti, M., Birkett, J. W., Chinyanga, E., Zvauya, R., Scrimshaw, M. D. and Lester, J. N. (2006): Heavy metal content of vegetables irrigated with mixture of waste water and sewage sludge in
Zimbabwe: implications for human health. Agriculture, Ecosystem and Environment. 112, 4148.

[34] Mullins, G. L., Martenz, D. C., Miller, W. P., Konegay, E. T. and Hallock, D. L. (1982): Copper availability, form and mobility in soils from three annual copper-enriched Hog Manure Application. Journal of Environmental Quality. 11, 316-320.

[35] Naser, H. M., Shil, N. C., Mahmud, N. U., Rashid, M. H. and Hossain, K.M. (2011): Lead, Cadmium and Nickel contents of vegetables grown in industrially polluted and non-polluted areas of Bangladesh. Bangladesh Journal of Agricultural Research. 34, 545-554.

[36] Njoku, P. C. and Ayoka, A. O. (2007): Evaluation of heavy metal pollutant from soils at municipal solid waste deposit in Owerri, Imo State, Nigeria. Journal of Chemical Society of Nigeria. 32(1), 5260.

[37] Ogundele, D. T., Adio, A. A. and Oludele, A. A. (2015): Heavy metals concentration in plants and soil along heavy traffic road in North Central Nigeria. Journal of Environmental and analytical Toxicology. 5, 334.

[38] Ogunfowokan, O. A., Oyekunle, J. A. O., Olutona, G. O., Atoyebi, A. O. and Lawal, A. (2013): Speciation study of heavy metals in water and sediments from Asunle River of the Obafemi Awolowo University, Ile-Ife, Nigeria, International Journal of Environmental Protection. 3, 6-16.

[39] Oluwatosin, G. A., Adeoyolanu, A. O., Ojo, A. O., Are, K. S., Dauda, T. O. and Aduramigba-modupe, V. O. (2010): Heavy metal uptake and accumulation by edible leafy vegetable (Amaranthus hybridus) grown on urban valley bottom soils in Southwestern Nigeria. Soil and Sediment Contamination. 19, 1-20.

[40] Oluyemi, E. A., Feuyit, G., Oyekunle, J. A. O. and Ogunfowokan, A. O. (2008): Seasonal variations in heavy metals concentrations in soil and some selected crops at a landfill in Nigeria. African Journal of Environmental Science and Technology. 2, 89-96.

[41]Rattan, R. K., Datta, S. P., Chhonkar, P. K., Suribabu, K., Singh, A. K. (2005): Long-term impact of irrigation with sewage effluents on heavy metal content in soils, crops and groundwater-a case study. Agriculture, Ecosystem and Environment. 109, 310-322.

[42] Richter, J., Schnitzler, W. H. and Gura, S. (1995): Vegetable production in peri-urban areas in the tropics and sub-tropics: food, income and quality of life. Gura, S. (ed.) Proceedings of an International Workshop, DSE, Feldafing, Germany. Oxford 
University Press for the Asian Development Bank, Oxford.

[43] Sharma, R. K., Agrawal, M. and Marshall, F. M. (2005): Heavy metals contamination in vegetables grown in wastewater irrigated areas of Varanasi, India. Bulletin of Environmental Contamination and Toxicology. 77, 311-318.

[44] Sharma, R. K., Agrawal, M. and Marshall, F. M. (2008b): Atmospheric depositions of heavy metals $(\mathrm{Cd}, \mathrm{Pb}, \mathrm{Zn}$ and $\mathrm{Cu})$ in Varanasi India. Environmental Monitoring and Assessment. 142(13), 269-278.

[45] Sloof, W., Clevan, R. F., Janus, J. A. and Ros, J. P. M. (1989): Integrated Criteria Document Cu. Report no. 758474009. National Institute of Public Health and Environmental Protection, Bilthoven, Netherlands.

[46] Smit, J., Ratta, A. and Nasr, J. (1996): In: Urban Agriculture: Food, Jobs and Sustainable Cities. UNDP. Publication series for Habitat II, New York.

[47] Sridhara, N. C., Kamala, C. T., Samuel, D. and Suman, R. (2008): Assessing risk of heavy metals from consuming food grown on sewage irrigated soil and food chain transfer. Ecotoxicology and Environmental Safety. 69(3), 513-524.

[48] Taylor, M. D. (1997): Accumulation of Cd derived from fertilizer in New Zealand Soils. Science of Total Environment. 208,123-126.

[49] Thandi, N. K., Nyamangara, J. and Bangira, C. (2004): Environmental and potential health effect of growing leafy vegetables on soil irrigated using sewage sludge and effluent: A case of $\mathrm{Zn}$ and $\mathrm{Cu}$. Pesticides, Food Contaminants and Agricultural Wastes. 39,461-471

[50] Turkdogan, M. K., Kilicel, F., Kara. K., Tuncer, I. and Uygan, I. (2002): Heavy metals in soil, vegetables and fruits in the endemic upper gastrointestinal cancer region of Turkey. Environment, Toxicology and Pharmacology. 13, 175-179. Doi. 1016/S13826689(02)00156-4.

[51] USEPA, (2002): Multimedia, Multi-pathway and Multi-receptor Risk Assessment (3MRA) Modellling System. Environmental Protection Agency, Office of Research and Development, Washington DC, pp. 1-9.

[52]USEPA (United States Environmental Protection Agency) (IRIS) (2009): Integrated Risk Information System-database. Philadelphia PA; Washington, DC USEPA (2010): Exposure Factors Handbook General Factors. EPA/600/P-95/002Fa, vol. I. Office of Research and Development. National Center for Environmental Assessment. US Environmental Protection Agency. Washington.
[53] Walkley, A. and Black, I. A. (1934): An examination of the pegiareff method for determining soil organic matter and a proposal on modification of the chromic acid titration method. Soil Science. 327, 29-32.

[54](WHO) (2006): Guidelines for the safe use of wastewater, excreta and grey water: Wastewater use in agriculture (Volume II). Retrieved from persistent URL:http://www.who.int/water_sanitation_health/w astewater/gsuweg2/en/index.html

[55]Zhou, F., Guo. H. and Hao, Z. (2007): Spatial distribution of heavy metals in Hong kong's marine sediments and their human impacts: A GIS based Chemometric Approach. Marine Pollution Bulletin. 54(9),

1372-1384.

Doi:10.1016/j.marpolbul.2007.05.017.

[56]Zhuang, P., Zou, B., Li, Z. A. (2009): Heavy metal contamination in soils and food crops around Dabaoshan mine in Guangdong, china: implication for human health. Environmental Geochemistry and Health. Doi:10.1007/s10653-009-9248-3.

[57]Zude, A. (2000): Determination of $\mathrm{Pb}$ in blood, M.Sc.Thesis. An-Najah National University. 